\title{
NEW DATA ON TWO GAMASID MITES (ACARI: MESOSTIGMATA) FROM RUSSIA
}

\section{Omid Joharchi ${ }^{*}$, Irina I. Marchenko², Richard W. Hofstetter ${ }^{3}$ and Vladimir V. Abramov ${ }^{4}$}

\author{
${ }^{1} \mathrm{X}$-BIO Institute, Tyumen State University, Tyumen, Russia \\ ${ }^{2}$ Institute of Systematics and Ecology of Animals, Novosibirsk, Russia \\ ${ }^{3}$ School of Forestry, Northern Arizona University, Flagstaff, USA \\ ${ }^{4}$ Independent Researcher, Suvorov, Russia \\ *corresponding author; e-mail: j.omid2000@gmail.com
}

\begin{abstract}
We present the first record of Longoseius (Longoseius) longus (Mesostigmata: Digamasellidae) from Russia. It was collected on a longhorn beetle Stictoleptura variicornis (Dalman) (Coleoptera: Cerambycidae). In addition, a detailed redescription of the female Leioseius mirabilis Nikolsky, 1981 (Mesostigmata: Ascidae) is provided. This species, known only from the type series, was found in coniferous-deciduous forest litter in eastern Russia (Primorye Territory). Our work also presents the first description of the male Leioseius mirabilis.
\end{abstract}

KEY WORDS: Beetle-associated mites, Parasitiformes, Ascoidea, Rhodacaroidea, systematics, Ascidae, Digamasellidae, Ascinae, first record.

DOI: 10.21684/0132-8077-2021-29-1-81-93

\section{INTRODUCTION}

Mesostigmata is a large, cosmopolitan order of mites that includes approximately 11,500 valid species, which is about $20 \%$ of all known mite species (Beaulieu et al. 2011). The representatives of this order are characterized by an unusually diverse variety of lifestyles and habitats, but the majority of species are free-living predators. Mesostigmatic mites are found in soil, litter, rotting wood, compost, manure, carrion, nests, house dust and similar detritus-based niches. They are also associated with plants and fungi (Lindquist et al. 2009). The mite family Ascidae includes 17 genera and slightly over 370 described species (Moraes et al. 2016; Lindquist and Moraza 2018; Santos and Moraes 2016; Kazemi 2019). Within the Ascinae subfamily, Leioseius is presumed to be a group of predatory mites of small arthropods or nematodes, based on their cheliceral morphology (Lindquist and Moraza 2018). The genus comprises 23 nominal species that occur either in soil and litter habitats or in seashore debris and niches throughout most of the world, except high alpine and polar areas (Lindquist and Moraza 2018; Santos and Moraes 2016; Kazemi 2019). Deutonymphs and adults of many families of Mesostigmata have established close phoretic relationships with other arthropods, and phoresy by deutonymphs is a common phenomenon among the Digamasellidae family (Lindquist et al. 2009).

As a result of continued confusion about the definition and status of some of its genera, the classification of Digamasellidae is unstable. Different concepts of genera and subgenera have been used by different authors (e.g., Lindquist 1975; Evans and Till 1979; Shcherbak 1980; Hirschmann and Wiśniewski 1982; Karg 1993). We herein follow Lindquist (1975) and subsequent authors (e.g., Castilho et al. 2012), who classified Digamasellidae into relatively few genera. The genus Longoseius Chant, 1961 includes nine nominal species distributed across two subgenera. Mites of this genus are almost always found in association with subcortical (especially woodboring and bark) beetles found under the bark of various trees. Deutonymphs of Longoseius are typically phoretic on their host carriers (e.g., cerambycids, scolytids) (Lindquist 1975; Castilho et al. 2012).

This paper is part of a project that aims to enhance our collective knowledge of Russia's mite fauna. Towards this aim, we report Longoseius (L.) longus (Hirschmann, 1960) for the first time from Russia. The specimens were collected on a longhorn beetle Stictoleptura variicornis (Dalman) (Coleoptera: Cerambycidae). Furthermore, a detailed redescription of the female Leioseius mirabilis Nikolsky, 1981 is provided. The redescription is based on the type series, as well as on additional specimens collected from the Primorye Territory and Buryatia (Eastern Siberia). Our work also includes the first description of the male of $L$. mirabilis.

\section{MATERIALS AND METHODS}

After being collected from different habitats (mostly forests) by individual hand picking, the 


\section{O. Joharchi et al.}

host beetles were individually placed in vials with $96 \%$ ethanol. Mites were removed from the beetles themselves as well as from the alcohol sediments (which were also inspected for phoretic mites), cleared in lactic acid solution and mounted in Hoyer's medium (Walter and Krantz 2009).

The line drawings and examinations of the specimens were performed with the Zeiss Axio Imager A2 and Leica DM 2500 compound microscopes, equipped with the differential interference contrast (attached to the AxioCam ICc 5 camera), as well as with phase contrast (attached to the ICC50 HD camera). The resulting images were processed using the Adobe Photoshop CS2 software based on the line drawings. Images and morphological measurements were taken using the following software: ZEN 2012 (v. 8.0), Leica Application Suite (LAS) (v. 4.2, Live and Interactive Measurements modules). Micrographs were taken with the AxioCam 506 camera (Carl Zeiss, Germany). Differential interference contrast (DIC) micrographs were taken using the Carl Zeiss Axio Imager A2 compound microscope's digital camera.

Measurements of structures are expressed as ranges (minimum-maximum) in micrometers $(\mu \mathrm{m})$. The length and the width of the dorsal shield were taken from the anterior to the posterior margins along the midline and at the level of $r 4$, respectively; the length and width of the idiosoma, including the dorsal shield and the soft marginal cuticle, were measured in a similar manner. The length measurement of the sternal shield was taken at the maximum length. The width of the sternal shield was measured at the broadest points (at the level of the endopodal between coxae II and III). The length of the genital shield was measured along the midline, from the anterior margin of the hyaline extension to the posterior margin of the shield. The width of the genital shield was measured from lateral margins, at the level of st5. The ventrianal shield length was taken from the anterior to posterior margins along the midline, including the cribrum. The ventrianal shield width was taken from lateral margins at the broadest point. Leg length was measured from the base of the coxa to the apex of the tarsus (excluding pre-tarsus).

The notation for idiosomal setae follows Lindquist and Evans (1965), modified slightly by Lindquist (1994). The notation for leg and palp setae follows that of Evans $(1963,1964)$. Notations for the idiosomal pore-like structures (gland pores and poroids/lyrifissures) follow mostly that of Athias-Henriot $(1971,1975)$. Notation for pore-like structures of the peritrematal region follows that of Johnston and Moraza (1991).

\section{SYSTEMATICS}

\section{Family Ascidae Oudemans}

Genus Leioseius Berlese

Lasioseius (Leioseius) Berlese, 1916: 45.

Type species: Ameroseius minusculus Berlese, 1905, by original designation.

Diagnosis. The concept of Leioseius used here is based on that of Moraes et al. (2016) and Lindquist and Moraza (2018) with modifications by Kazemi et al. (2019).

\section{Leioseius mirabilis Nikolsky, 1981}

(Figs. 1-4)

Leioseius mirabilis Nikolsky, 1981: 20.

Leioseius mirabilis-Moraes et al. 2016: 120; Santos and Moraes, 2016: 61; Lindquist and Moraza, 2018: 2015.

Diagnosis (female). Dorsal shield with wellformed lateral incisions between setae $s 6$ and $S 1$, reticulated, scabrous, more distinct in opisthonotal and lateral regions, and also behind setae $J 4$, shield with 32 pairs of setae, including 17 pairs on podonotal region, $j 1-6, z 1-z 2, z 4-z 6$ ( $z 3$ absent), $s 1-6$, and 15 pairs on opisthonotal region, all marginal $r$ - $R$-setae on soft cuticle, setae mostly smooth, except $Z 3-5$ and $S 5$ with a few barbs, $Z 5$ longest. Presternal area lightly sclerotized, punctate, comprises few transverse curved lines anteriorly and a pair of sclerotized smooth platelets posteriorly which bear setae $s t 1$. Ventrianal shield subtrapezoidal, with two pairs of opisthogastric setae ( $J v 3$ and $J v 5)$ (excluding circumanals) and one pair of gland pores $(g \vee 3)$, shield posterior margin scalloped. Epistome with three denticulate prongs, central prong longer than lateral prongs; hypostomal groove with seven rows of denticles, each row with 2-6 denticles, with smooth anterior and posterior transverse lines, movable digit of chelicera with two well-spaced teeth in addition to apical hook, fixed digit of chelicera with 11 teeth. Leg I genu and tibia each with 13 setae, $a v 2$ and $p d 3$ present; genua III and IV each with nine setae.

Redescription. Female $(\mathrm{n}=10)$. Brownish in colour.

Dorsal idiosoma (Figs. 1A, 2A). Dorsal idiosoma 532-586 long, 259-275 wide, 216-252 wide at level of $R 3$, dorsal shield 510-560 long, 207-228 wide, 190-210 wide at level of $R 3$, reticulated, sca- 


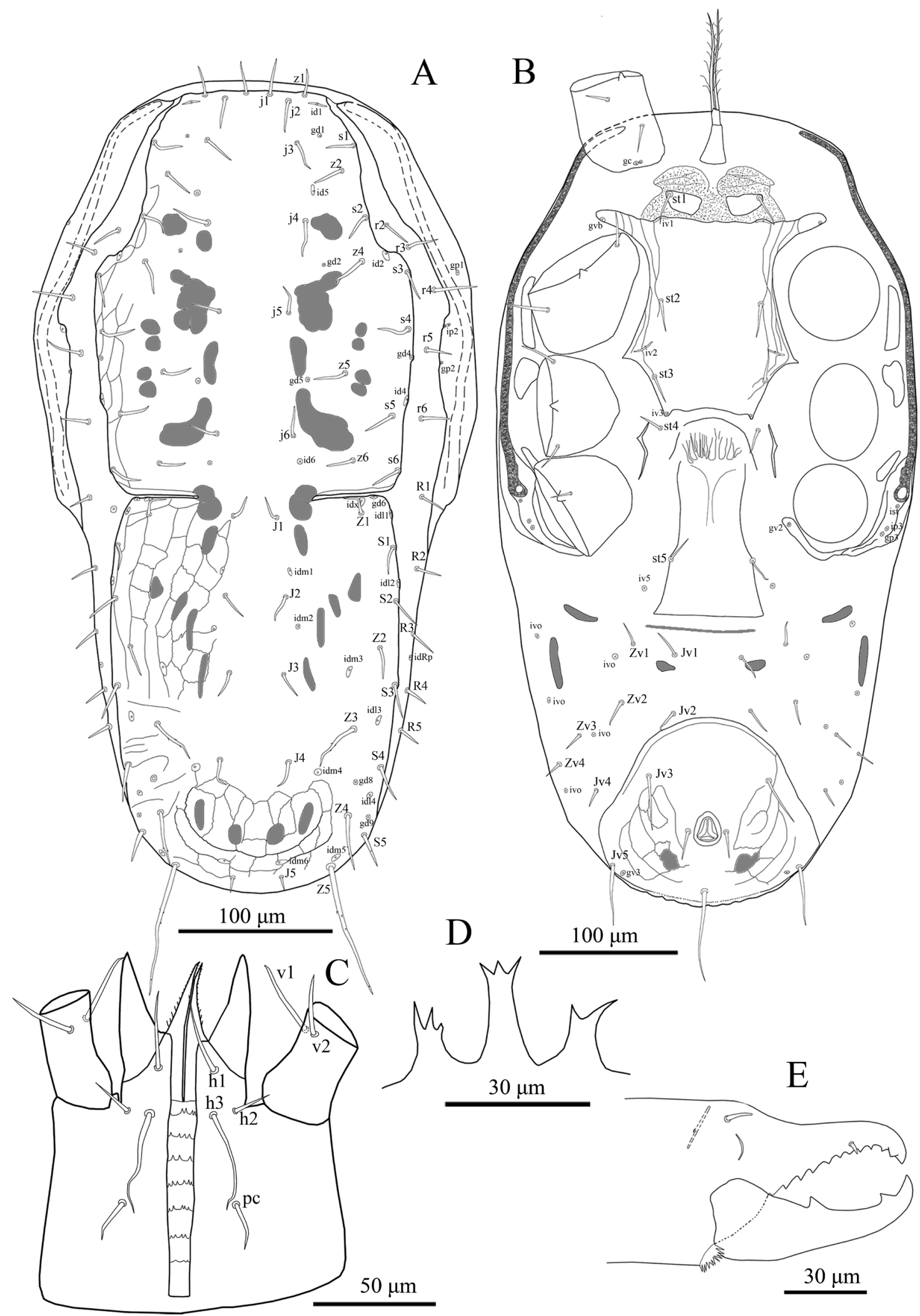

Fig. 1. Leioseius mirabilis Nikolsky, 1981, female. A-dorsal idiosoma; B-ventral idiosoma; C—subcapitulum; D-epistome; E-chelicera. 


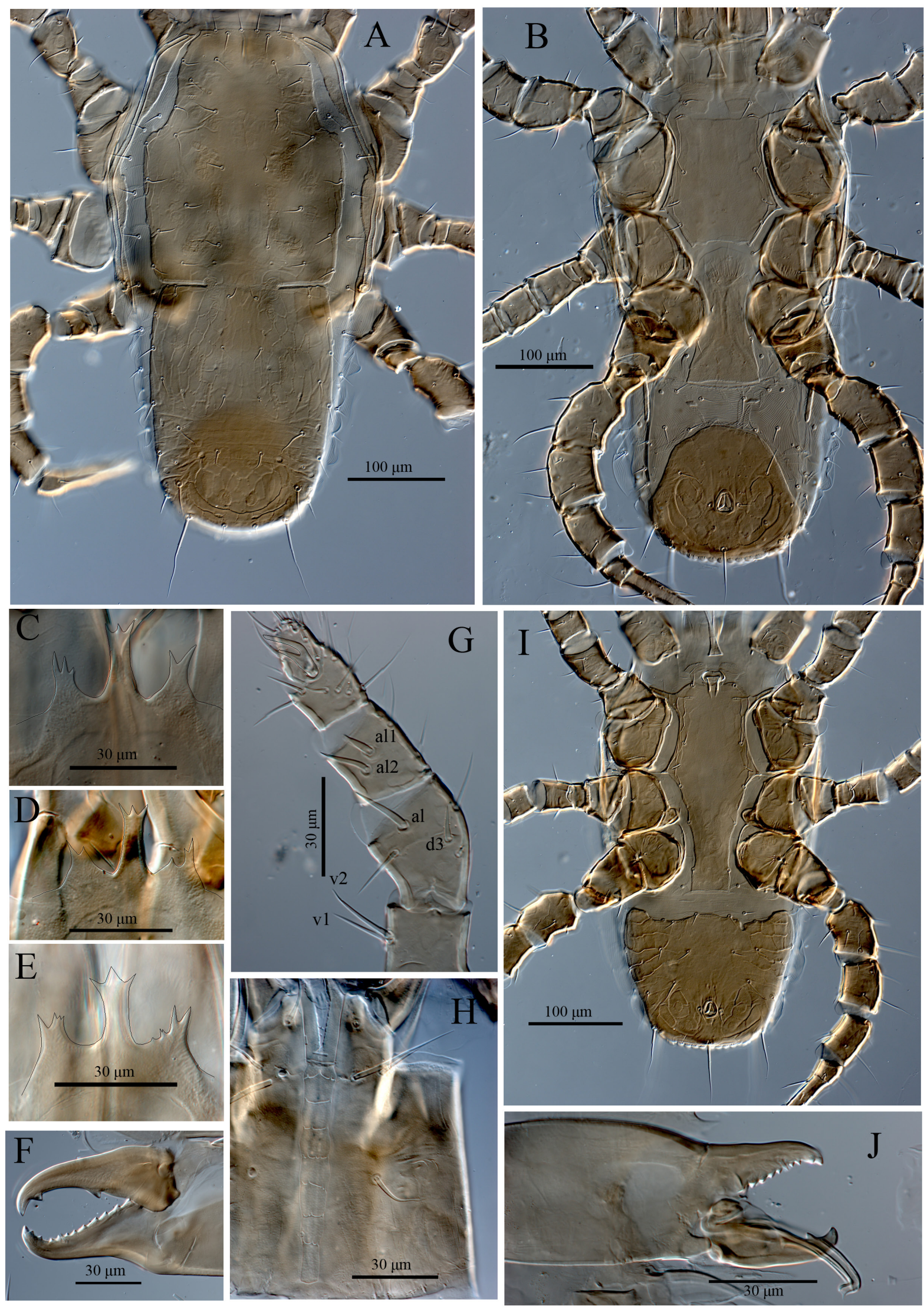

Fig. 2. DIC micrographs of Leioseius mirabilis Nikolsky, 1981, female (paratype). A-idiosoma, dorsal view; Bidiosoma, ventral view; $\mathrm{C}-\mathrm{E}$ - variations in epistome; $\mathrm{F}$ - chelicera; $\mathrm{G}$ - distal portion of palp, with a focus on apotele; $\mathrm{H}$ - hypostomal groove of subcapitulum; male. I—idiosoma, ventral view; J—chelicera. 

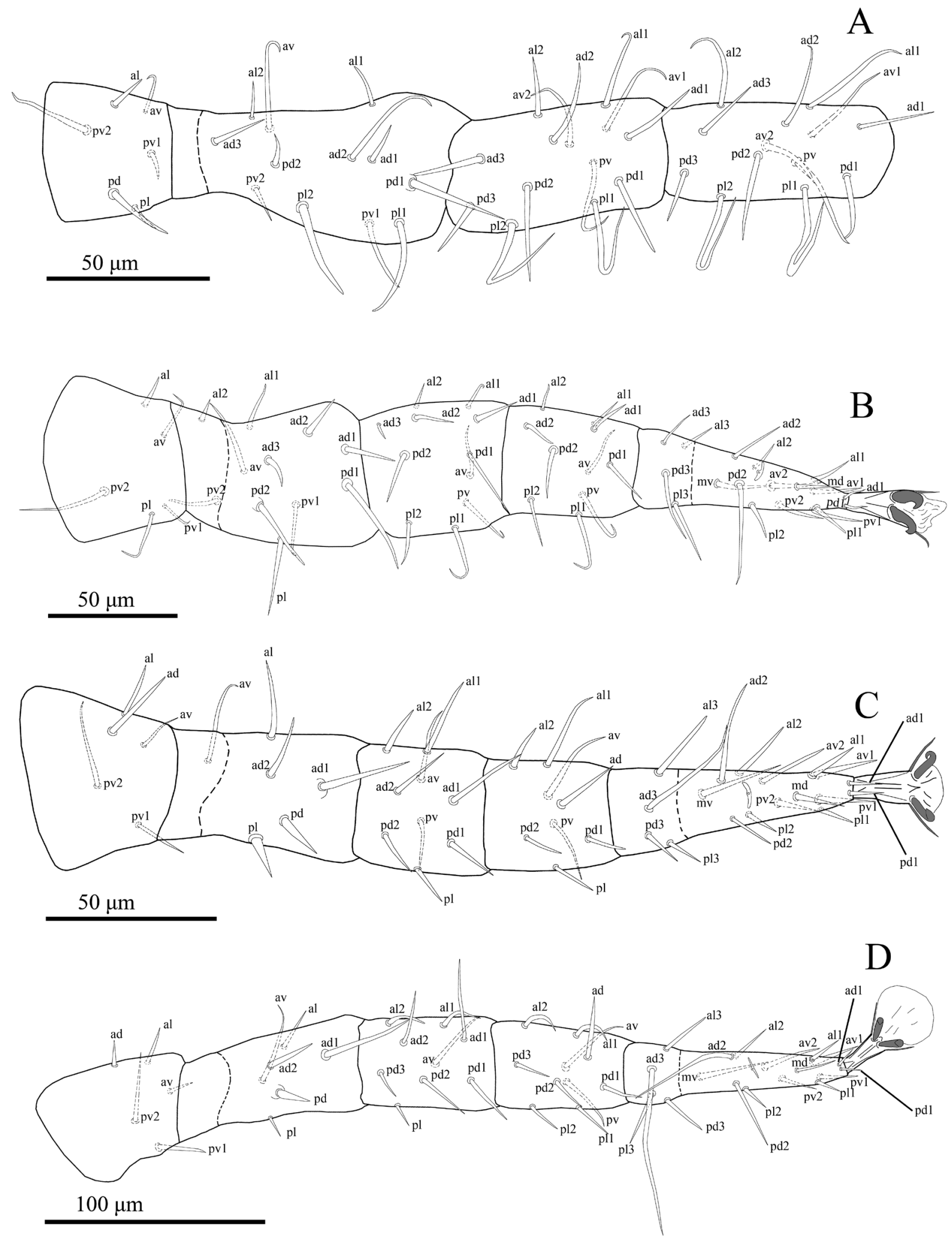

Fig. 3. Leioseius mirabilis Nikolsky, 1981, female. A—leg I (trochanter-tibia); B-leg II; C—leg III; D—leg IV.

brous, more distinct in opisthonotal and lateral regions, and also behind setae $J 4$ (Figs. 1A, 2A), shield with well-formed lateral incisions between setae $s 6$ and $S 1$, bearing 32 pairs of setae, including 17 pairs on podonotal region, $j 1-6, z 1-z 2, z 4-z 6(z 3$ absent), $s 1-6, r 2-6$ on the lateral soft cuticle; and 15 pairs on opisthonotal region, $R 1-5$ on the lateral soft cuticle, setae mostly smooth, except $Z 3-5$ and $S 5$ 


\section{O. Joharchi et al.}

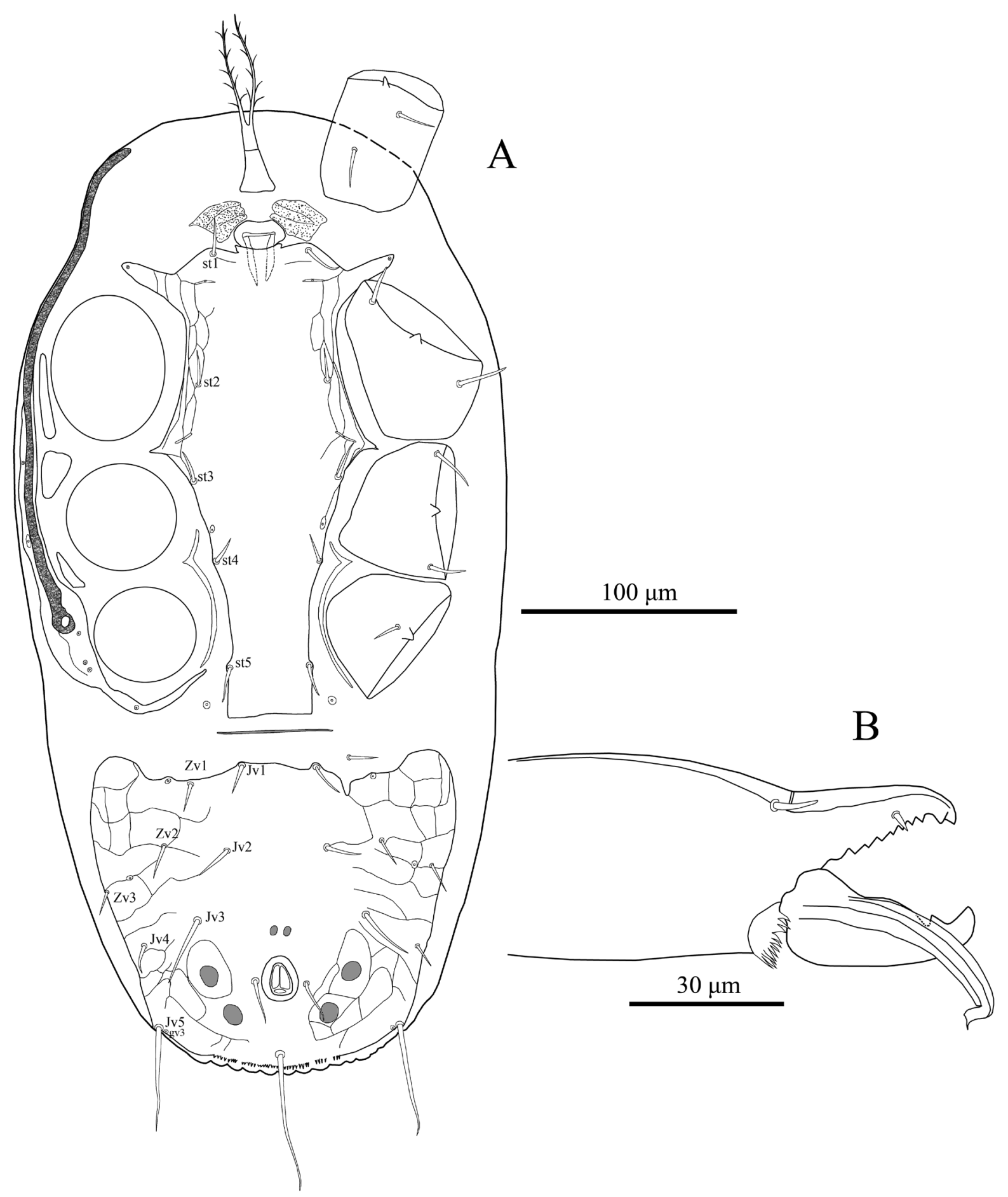

Fig. 4. Leioseius mirabilis Nikolsky, 1981, male. A-ventral idiosoma; B-chelicera.

with a few barbs. Dorsal idiosomal setae 14-25 long, r4 27-33, Z3-4 34-42, J5 8-10 shortest and Z5 longest (87-94), Z5/J5 ratio approx. $=9-11$. Shield with about 23 pairs of discernible pore-like structures, including seven pairs of gland openings $(g d 1-2, g d 4-6$ and $g d 8-9)$ and 16 poroids $(i d 1, i d 2$, $i d 4-i d 6, i d m 1-i d m 6$, idx and idl1-idl4) others indistinct (Figs. 1A and 2A). Lateral soft cuticle with ten pairs of setae, $r 2-6$ and $R 1-5$, and a pair of poroids
(idRp). Muscle-marks (sigillae) as illustrated and showed in Figs. 1A and 2A.

Ventral idiosoma (Figs. 1B, 2B). Tritosternum with paired pilose laciniae (62-67), fused basally (7-10), columnar base 28-32 × 18-22 wide; presternal area lightly sclerotized, punctate, comprises with a few transverse curved lines anteriorly and a pair of sclerotized platelets posteriorly which bear setae st1 (17-20). Sternal shield length 
133-138, narrowest between coxae II (86-92), widest (122-130); bearing two pairs of smooth setae (17-20) (st2, st3), two pairs of lyrifissures (iv1, iv2) and one pair of sub-oval poroids on posterolateral corners of shield margin (iv3), endopodals between coxae I-II fused with sternal shield, bearing $g v b$ on their distal edges, surface of sternal shield without reticulate ornamentation, almost smooth, except some irregular longitudinal lines laterally (Figs. 1B, 2B). Setae st4 (17-20) on soft cuticle. Endopodal strips narrow between coxae III and IV. Genital shield smooth, somewhat vase form, anterior margin of shield convex, not overlapping posterior area of sternal shield, posterior margin truncate, widened 66-82 (broadest point), 53-62 wide at level of setae st5, 137-145 long, setae st 5 (17-20) on lateral margins of shield (Figs. 1B, 2B). Paragenital poroids (iv5) located on soft cuticle beside posterolateral margins of shield (near seta $s t 5$ ). Ventrianal shield subtrapezoidal, anterior margin of shield convex; shield length 135-146, width $111-122$ at $J v 3$ level and width $153-169$ at para-anal level (broadest point); surface slightly reticulated, with two pairs of opisthogastric setae, Jv3 22-31 and Jv5 42-53, plus para-anal (15-18) and postanal (65-70) setae, its lateral margins not bearing setae $J v 4$ but diverging posteriorly to bear setae $J v 5$, shield posterior margin scalloped (Figs. 1B, 2B), narrow cribrum flanked by gland pores $g v 3$. Opisthogastric soft cuticle with faintly sclerotized postgenital platelets behind strip-like postgenital groove, seven pairs of setae (16-19) $(J v 1-2, J v 4, Z v 1-4)$; two pairs of well-spaced metapodal platelets [elongate lateral pair 37- 44 long, 6-8 wide, small inner pair dimensions $21-26$ by 3-6], and five pairs of poroids ivo (Figs. 1B, 2B). Peritremes long, extending from stigma to region between levels of $s 1$ and $z 1$. Peritrematal shields anteriorly fused with dorsal shield at level between setae $z l$ and posteriorly united with exopodal strip extending behind stigma around posterior margin of coxa IV, but free from exopodal fragments alongside coxae II-IV, shields bearing seven pairs of discernible pore-like structures: four pairs of gland pores (including $g v 2$ ) and three pairs of poroids (Figs. 1A, 1B, 2A, 2B).

Gnathosoma (Figs. 1C-E and 2C-H). Anterior margin of epistome with three denticulate prongs, central prong longer than lateral prongs (Figs. 1D and $2 \mathrm{C}-\mathrm{E}$ ). Hypostomal groove with seven transverse rows of denticles, each row with 2-6 denticles, with smooth anterior and posterior transverse lines
(Figs. 1C and 2H). Hypostome with four pairs of smooth setae, $h 3(36-40)>h 1(21-23)>p c$ (1922) $>h 2$ (17-20). Corniculi subparallel, robust and horn-like, with bluntly pointed tips, longer than internal malae, extending mid-level of palpfemur. Supralabral process not distinguishable. Internal malae with one pair of fimbriate projections (Figs. 1C); labrum markedly longer than internal malae with pilose surface. Palptarsal claw two-tined, all setae on palps smooth and needle-like except setae $v 1$ and $v 2$ on trochanter thickened, $a l$ and $d 3$ on femur, all-2 on genu somewhat spine-like; palptarsus without long setae (Fig. 1G). Second segment of chelicera (including the fixed digit) 153-156 long, fixed digit of chelicera with an offset distal tooth (gabelzahn), followed by ten more or less same sized teeth, a relatively short pilus dentilis, dorsal cheliceral seta thick, prostrate, arthrodial membrane with a rounded flap and some filaments, cheliceral lyrifissures distinct; movable digit of chelicera (73-77 long) with two well-spaced teeth in addition to apical hook (Figs. 1E and 2F).

Legs (Fig. 3A-D). Legs II (341-358) and III (297-339) short, I (416-425) and IV (481-489) longer. Chaetotaxy (legs I-IV): Leg I (Fig. 3A): coxa $0-0 / 1,0 / 1-0$, trochanter $1-0 / 1,1 / 2-1$ ( $p d$ and al thickened), femur 2-3/1, 2/2-2 ( $p l 1$ and $p d l$ thickened, $p d 1$ inserted on small tubercles), genu 2-3/2, 3/1-2 (av2 present), tibia 2-3/2, 3/1-2 (av2 present). Leg II (Fig. 3B): coxa 0-0/1, 0/1-0, trochanter 1-0/1, 0/2-1, femur 2-3/1, 2/2-1 (all dorsal setae slightly thickened and $p d 2$ inserted on small tubercles), genu 2-3/1, 2/1-2, tibia 2-2/1, 2/1-2. Leg III (Fig. 3C): coxa $0-0 / 1,0 / 1-0$, trochanter $1-1 / 1,0 / 2-0$, femur 1-2/1, 1/0-1 (all, adl, ad2 thickened and adl inserted on small tubercles, $p d$ and $p l$ somewhat spinelike), genu 2-2/1, 2/1-1, tibia: 2-1/1, 2/1-1. Leg IV (Fig. 3D): coxa 0-0/1, 0/0-0, trochanter 1-1/1, 0/2-0, femur 1-2/1, 1/0-1 (ad1 and $a d 2$ thickened, $a d 1$ longer than other setae of same respective segment, $p d$ somewhat spine-like, inserted on small tubercles), genu 2-2/1, 3/0-1 (ad1 slightly longer), tibia 2-1/1, 3/1-2 (ad1 slightly longer and thicker than other setae of same respective segment). Tarsi II-IV with 18 setae (3-3/2, 3/2-3+mv, $m d$ ); setae $p d 2$ of tarsus II and $a d 2, a d 3$ on tarsi III-IV distinctly longer (macrosetae) than other setae of same respective segment (Fig. 3B-D). All legs with pretarsi, including a pair of claws and pulvilli with median section rounded, claws on pretarsi I much smaller than on other legs. Legs II-IV with elongate and acuminate paradactyli (Fig. 3B-D). 


\section{O. Joharchi et al.}

Description. Male (n=2). (Figs. 2I-J and 4A-B). Dorsal idiosoma. Dorsal idiosoma 447-465 long, 230-234 wide, 200-202 wide at level of $R 3$, dorsal shield 453-456 long, 189-195 wide, 170173 wide at level of $R 3$; shield ornamentation, complement of pore-like structures and setation as in female.

Ventral idiosoma (Figs. 2I and 4A). Tritosternum formed as in female, with paired pilose laciniae (65-67), fused basally (11-13), columnar base 19-21 × 16-18 wide. Presternal region with a pair of distinct platelets flanking genital opening. Sternitigenital shield length 218-220, narrowest between coxae IV (34-36), widest at level between coxae II-III (103-108); posterior margin width 40-43; shield lineated along lateral margins alongside setae $s t 1-s t 3$, unornamented medially and posteriorly, free from endopodal strips beside coxae III-IV; setae st1-st5 similar in length (1317). Poroids $i v 5$ on soft cuticle, postgenital groove strip-like without platelets, as in female. Ventrianal shield lightly reticulated over most of surface except lateral regions, its anterior margin undulating and posterolateral margins not abruptly constricted in anal region; shield wider (180-185) than long (146-149); shield with all eight pairs of opisthogastric setae present; in one specimen right $Z v 1$ off the shield (Figs. 2I and 4A).

Gnathosoma. Epistome and subcapitulum similar to female. Fixed digit of chelicera with offset subapical tooth, pilus dentilis and seven teeth; movable digit (41-44) unidentate; spermatodactyl 47-50 long, extending anteriorly 16-19 beyond apex of digit with narrowed apex curving outwards (Figs. 2J and 4B). Form and length of other gnathosomatic structures as in female.

Legs. Legs similar to those of female, without dimorphism in thickness or spine-like setal modifications. Lengths I 363-370, II 309-316, III 279-285, IV 390-395.

Specimens examined: holotype female and 2 paratype females, Far East of Russia, Primorye Territory, Ussuriisky Natural Reserve, 18 September 1978, V. Nikolsky coll., from coniferous-deciduous forest litter; paratype female, Primorye Territory, Anuchinskii District, 30 July 1979, V. Bakurov coll., from coniferous-deciduous forest litter; 5 females, 2 males, Primorye Territory, Anuchinskii District, 30 July 1979, V. Bakurov coll., same habitat (deposited in the Zoological Museum of the Institute of Systematics and Ecology of Animals, Novosibirsk, Russia (ISEA); 1 female, East Siberia, Buryatia, $51^{\circ} 56^{\prime} \mathrm{N}, 102^{\circ} 24^{\prime} \mathrm{E}$, village of Arshan,
13 September 2020, L. V. Petrozhitskaya coll., from litter under Pinus sylvestris (Plantae: Pinaceae); holotype and three paratypes of Leioseius mirabilis Nikolsky, 1981 (deposited in ISEA).

Remarks. In Russia, Leioseius includes four identified species (Lindquist and Moraza 2018; Marchenko 2012, 2017): L. elongatus Evans, 1958, L. minusculus (Berlese, 1905), L. mirabilis Nikolsky, 1981 and L. naglitschi Karg, 1965. Leioseius mirabilis was originally described from Primorye Territory, Far East Russia (Nikolsky 1981). This species, known only from the type series, was found from coniferous-deciduous forest litter. However, the original description is brief and its illustrations are incomplete, lacking most important details, especially those concerning leg chaetotaxy. So, the species has never been fully redescribed. The diagnosis given above is based primarily on type series specimens. Opisthogaster in the genus Leioseius is usually with ventrianal shield, bearing 2-6 pairs of setae, in addition to circumanal setae. Ventrianal shield with two pairs of opisthogastric setae occurs in only three species of Leioseius (Lindquist and Moraza 2018): L. dolichotrichus Ma, 2002, L. minusculus (Berlese, 1905) and L. mirabilis. However, L. mirabilis is easily distinguished from L. minusculus by having deep lateral incisions on dorsal shield (reaching about the transverse level of setae jo), while in L. minusculus lateral incisions of dorsal shield shallow. Leioseius mirabilis differs from $L$. dolichotrichus because its ventrianal shield is with scalloped posterior margin and setae $s t 1$ is on presternal platelets (anterior to sternal shield) whereas in L. minusculus ventrianal shield with smooth posterior margin and setae st 1 on soft cuticle, anterior to sternal shield.

Based on the holotype and the paratypes, the female of L. mirabilis was described and illustrated by Nikolsky (1981) as having a hypostomal groove with six transverse rows of small denticles. This aspect was viewed as an exception to the diagnosis concept of the Leioseius genus by Moraes et al. (2016: 25). However, our observations of the holotype and the paratypes indicate that the hypostomal groove is normal, with seven transverse rows of denticles, each row with 2-6 denticles (Figs. $1 \mathrm{C}$ and $2 \mathrm{H}$ ). Nothing is known about the feeding patterns or any other aspects of L. mirabilis's behavior. Its morphology is similar to that of other free-living species: well dentate chelicerae, sclerotized and horn-like corniculi, etc. This fact suggests that it may be a predator of small invertebrates. We stress that further experimental work 
is needed to establish the true role of this mite in its respective ecosystems.

\section{Family Digamasellidae Evans}

\section{Genus Longoseius (Longoseius) Chant}

Longoseius Chant 1961: 11.

Type species: Longoseius (Longoseius) cuniculus Chant, 1961, by original designation.

Diagnosis. The concept of Longoseius (Longoseius) used here is based on that of Lindquist (1975).

\section{Longoseius longus (Hirschmann, 1960)}

(Figs. 5-6)

Dendrolaelaps longus - Hirschmann 1960: 15. Dendrolaelaps (Dendrolaelaps) longusHirschmann 1974: 62.

Longoseius longus—Shcherbak 1980: 170.

Longoseius (Longoseius) longus - Lindquist 1975: 20; Hirschmann and Wiśniewski 1982: 156.

Specimens examined: 15 deutonymphs, Russia, forest in the vicinity of the town of Suvorov $\left(54^{\circ} 07^{\prime} \mathrm{N}, 36^{\circ} 30^{\prime} \mathrm{E}\right), 17$ June 2019, V.V. Abramov coll., under elytra of Stictoleptura variicornis (Dalman) (Coleoptera: Cerambycidae). 3 deutonymphs, Portugal, Tróia Peninsula, June 2020, L. Bonifacio coll., on Monochamus galloprovincialis (Olivier) (Coleoptera: Cerambycidae) that emerged from cut down infested pines. All examined specimens of these two species have been deposited in the collection of the Tyumen State University Museum of Zoology, Tyumen, Russia.

Remarks. Lindquist (1975) erected two subgenera for the genus Longoseius: Longoseius and Longoseiulus. Specimens of the subgenus Longoseius are easily distinguished by several characters, including: an unusual degree of body elongation (at least four times longer than wide); losses of setae on the podonotal shield ( $\operatorname{setae} j 2, z 1, z 6, s 1-$ $s 3$ absent), legs (with many setal deficiencies; e.g., trochanter IV bearing three setae instead of normal five), palpgenu (with five setae instead of normal six); and two pairs of scleronoduli on podonotal shield absent (Lindquist 1975).

The Longoseius (Longoseius) comprises only two nominal species-L. (L.) cuniculus Chant and L. (L.) longus (Figs. 5-6) - which were found beneath tree bark, in association with wood-boring beetles in different regions of the USA and Europe, respectively. Longoseius (Longoseius) longus was described based on immature deutonymphs from Germany (Hirschmann 1960). It has been recorded from under the elytra of a click beetle species, Elater sanguineus (L.) (Coleoptera: Elateridae), from a stump of Picea sp. (Pinaceae). We have recorded this species from Russia for the first time, from under the elytra of a longhorn beetle species, Stictoleptura variicornis (Coleoptera: Cerambycidae).

The similarity of $L$. (L.) cuniculus and $L$. (L.) longus was noted by some authors (e.g., Soper and Olson 1963; Shcherbak 1980; Lindquist 1975), who suspected that they could be synonymous. Hurlbutt (1967) and Hirschmann and Wiśniewski (1982) tried to distinguish the two species by the number of denticles per row of hypostomal groove $(0-4$ denticles per row) (Fig. 5D; for L. (L.) cuniculus, see figs. 27-29 in Lindquist 1975), the orientation of the lateral tines of the epistome (Figs. 5E and 6D; for L. (L.) cuniculus, see fig. 32 in Lindquist 1975), the presence or absence of opisthonotal setae $J 2$ (Figs 5A-B, 6A-C; for L. (L.) cuniculus, see fig. 37 in Lindquist 1975 ), smooth or barbed opisthonotal setae $J 4$ and $Z 4$ (Figs. 5B and 6C; for L. (L.) cuniculus, see fig. 37 in Lindquist 1975), and the width of the hypostomal groove (Fig. 5D; for $L$. (L.) cuniculus, see figs. 27-29 in Lindquist 1975). However, our observations of the Russian and Portuguese specimens of $L$. (L.) longus indicate that there is a considerable degree of intraspecific variation in regards to all of the above-mentioned characters. Therefore, these characters cannot be used to reliably distinguish $L$. (L.) cuniculus from $L$. (L.) longus. It is worth mentioning that Lindquist (1975) also drew attention to the difficulty of clearly distinguishing one species from another due to the intraspecific variation of some of the abovementioned characters in $L$. (L.) cuniculus. After comparing the descriptions and figures of $L$. (L.) cuniculus provided by Chant (1961) and Lindquist (1975, figs. 36 and 37) with our observations of the Russian and Portuguese specimens of $L$. (L.) longus, we could not find any distinguishing authentic morphological differences in the deutonymph stages of the two species. Nevertheless, we provisionally retain them as two distinct species until further comparative studies of the adults of both species clarify their relationship.

Strictolptura variicornis commonly feeds within the xylem of dead and dying conifers. Its habitat ranges from northern Europe (e.g., Poland) to eastern Russia and also includes Mongolia and North Korea (Hofstetter et al. 2015). The ecological role of $L$. (L.) longus, associated with wood-boring beetle host carriers, is unknown (Hofstetter et al. 


\section{O. Joharchi et al.}
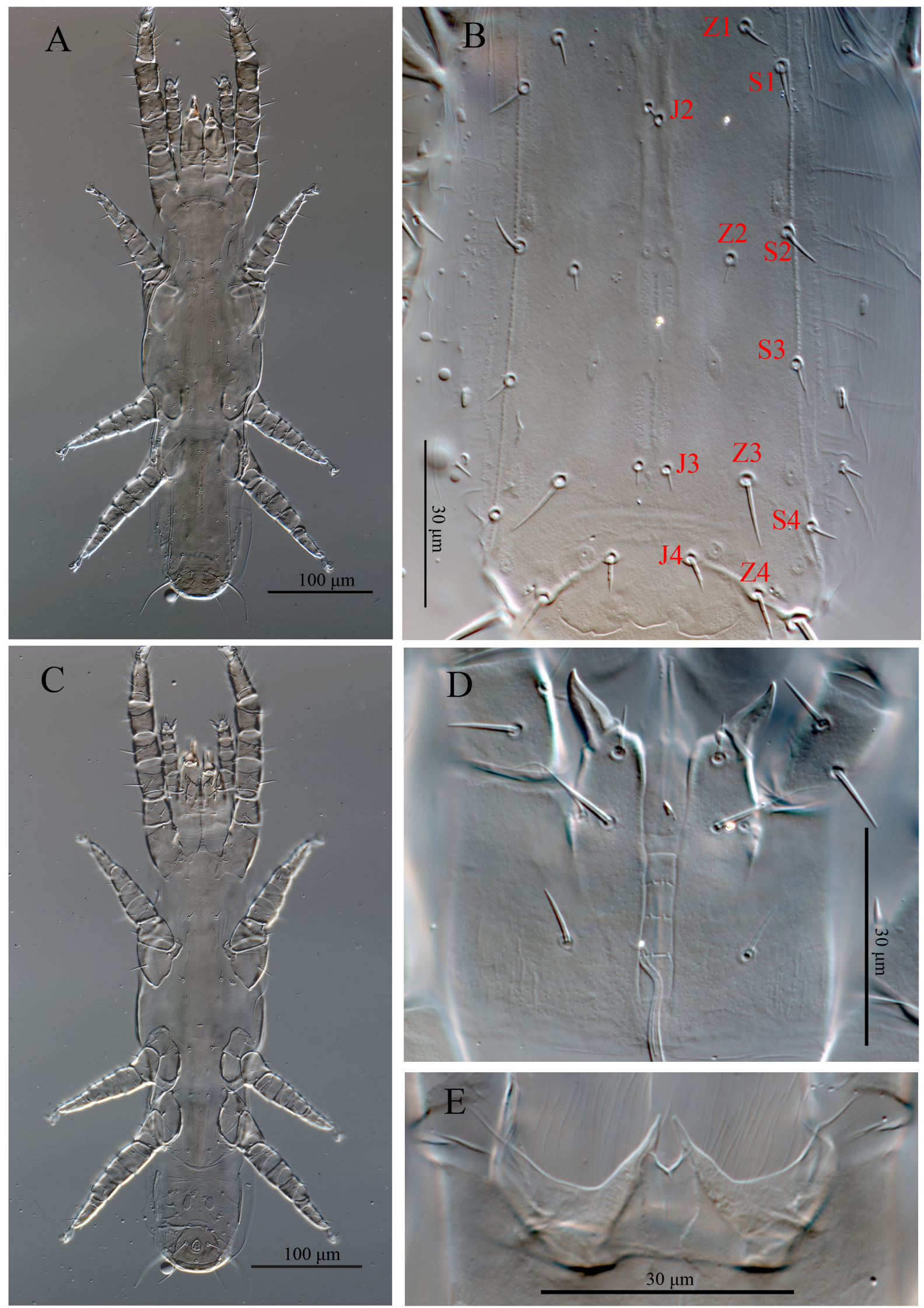

Fig. 5. DIC micrographs of Longoseius (Longoseius) longus (Hirschmann 1960), deutonymph. A—dorsal idiosoma; $\mathrm{B}$ - opisthonotal region of dorsal shield; C—ventral idiosoma; D — subcapitulum; E—epistome. 

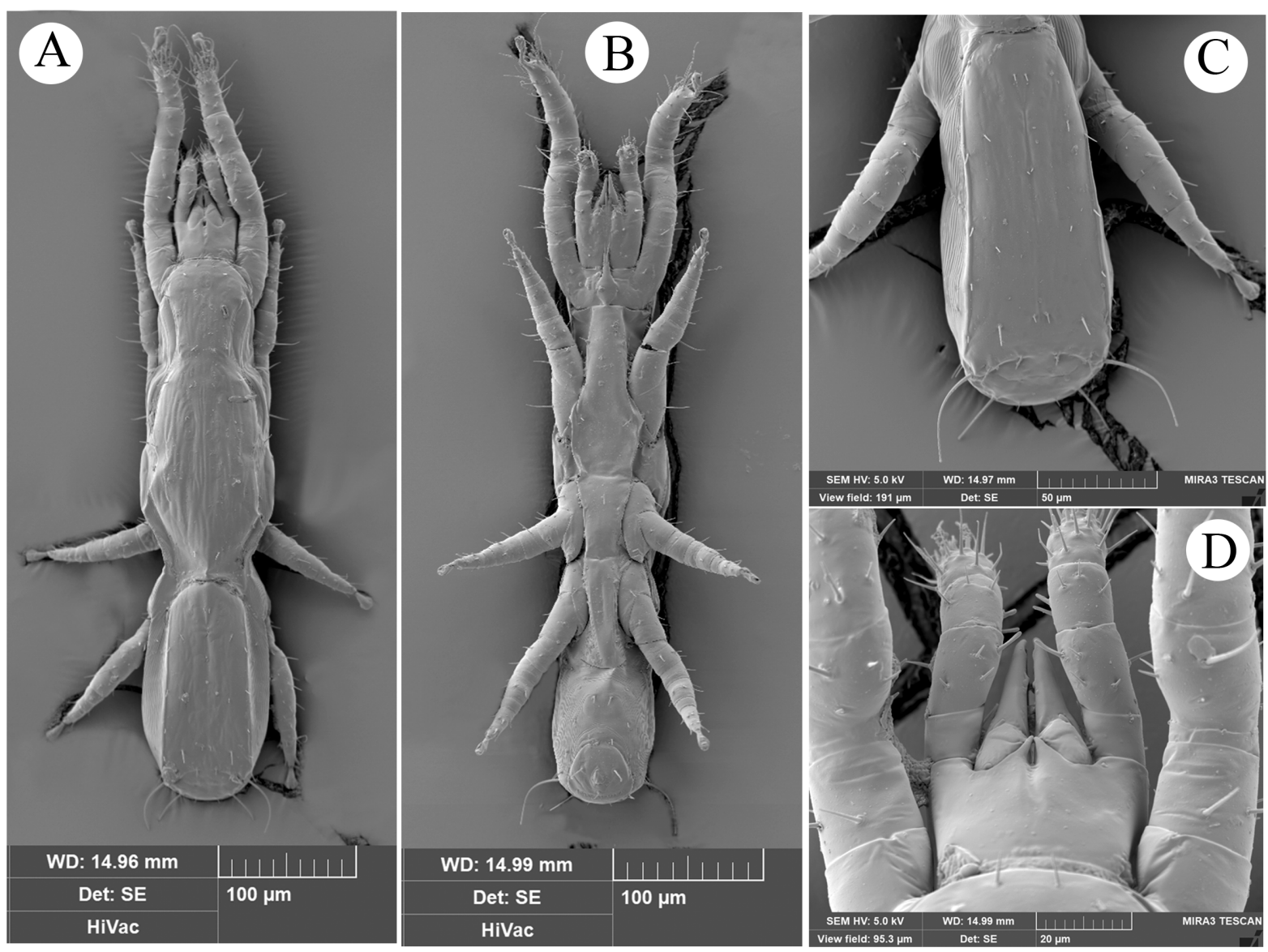

Fig. 6. SEM micrographs of Longoseius (Longoseius) longus (Hirschmann 1960), deutonymph. A-dorsal idiosoma; $\mathrm{B}$ - ventral idiosoma; C—opisthonotal region of dorsal shield; D—epistome.

2015). However, mites of the Longoseius genus are known to be predators of nematodes, arthropod eggs or young larvae, other mites and possibly fungi (Lindquist et al. 2009). Since none of the mites were swollen and only immature deutonymphs were found on the beetles, it seems that they are predators of small invertebrates that live in the wood-boring beetle galleries (beneath the bark). Therefore, it seems $L$. (L.) longus use beetle hosts just for transportation to new habitats (i.e. phoresy). We stress that experimental work is needed to establish the true ecological role of these mites.

\section{ACKNOWLEDGEMENTS}

This research was supported by a grant from the Russian Science Foundation, project № 20-64-47015.

\section{REFERENCES}

Athias-Henriot, C. 1971. La divergence néotaxique des Gamasides (Arachnides). Bulletin Scientifique de Bourgogne, 28: 93-106.

Athias-Henriot, C. 1975. Nouvelles notes sur les Amblyseiini. II. Le relevé organotaxique de la face dorsale adulte (Gamasides, protoadéniques, Phytoseiidae). Acarologia, 17: 20-29.

Beaulieu, F., Dowling, A.P.G., Klompen, H., de Moraes, G.J. and Walter, D.E. 2011. Superorder Parasitiformes Reuter, 1909. In: Z.-Q. Zhang (Ed.). Animal Biodiversity: An Outline of Higher-Level Classification and Survey of Taxonomic Richness. Zootaxa, 3148: 123-128.

Berlese, A. 1905. Acari nuovi. Materiali pel "Manipulus V". Redia, 2: 231-238.

Berlese, A. 1916. Centuria prima di Acari nuovi. Redia, 12: 19-67.

Castilho, R.C., de Moraes, G. J. and Halliday, B. 2012. Catalogue of the mite family Rhodacaridae Oudemans, with notes on the classification of the Rhodacaroidea (Acari: Mesostigmata). Zootaxa, 3471: 1-69.

Chant, D.A. 1961. A new genus and species of mite in the family Digamasellidae Evans (Acarina). Acarologia, 3: 11-13.

Evans, G.O. 1963. Observations on the chaetotaxy of the legs in the free-living Gamasina (Acari: Mesostigmata). Bulletin of the British Museum (Natural 


\section{O. Joharchi et al.}

History), Zoology, 10:275-303. DOI: 10.5962/bhl. part.20528

Evans, G.O. 1964. Some observations on the chaetotaxy of the pedipalps in the Mesostigmata (Acari). Annals and Magazine of Natural History, Series 13, 6:513-527. DOI: $10.1080 / 00222936308651393$

Evans, G. O. and Till, W.M. 1979. Mesostigmatid mites of Britain and Ireland (Chelicerata: Acari: Parasitiformes). Transactions of the Zoological Society of London, 35: 139-270.

Hirschmann, W. 1960. Gangsystematik der Parasitiformes. Teil 3. Die Gattung Dendrolaelaps Halbert 1915. Acarologie. Schriftenreihe für Vergleichende Milbenkunde, 3: 1-27.

Hirschmann, W. 1974. Gangsystematik der Parasitiformes. Teil 190. Die Gattung Dendrolaelaps Halbert 1915 Hirschmann nov. comb. Nova Subgenera Multidendrolaelaps, Tridendrolaelaps Hirschmann. Stadien von 4 neuen DendrolaelapsArten. Acarologie. Schriftenreihe für Vergleichende Milbenkunde, 20: 50-70.

Hirschmann, W. and Wiśniewski, J. 1982. Weltweite revision der Gattungen Dendrolaelaps Halbert 1915 und Longoseius Chant 1961 (Parasitiformes). Acarologie. Schriftenreihe für Vergleichende Milbenkunde, 29(1): 1-190; 29(2): 1-48 + Plates IXIV + Plates 1-94.

Hofstetter, R. W., Dinkins-Bookwalter, J., Davis, T.S. and Klepzig, K.D. 2015. Symbiotic associations of bark beetles. In: F.E. Vega and R.W. Hofstetter (Eds.). Bark Beetles: Biology and Ecology of $\mathrm{Na}$ tive and Invasive Species. Elsevier Academic Press, pp. 209-245.

Hurlbutt, H.W. 1967. Digamasellid mites associated with bark beetles and litter in North America. Acarologia, 9: 497-534.

Johnston, D.E. and Moraza, M.L. 1991. The idiosomal adenotaxy and poroidotaxy of Zerconidae (Mesostigmata: Zerconina). In: F. Dusbábek and V. Bukva (Eds.). Modern Acarology Vol. 2. Academia and The Hague, SPB Academic Publishing bv., Prague, pp. 349-356.

Karg, W. 1965. Larvalsystematische und phylogenetische Untersuchung sowie Revision des Systems der Gamasina Leach, 1915 (Acarina, Parasitiformes). Mitteilungen aus dem Zoologischen Museum in Berlin, 41: 193-340 + tab. 6. DOI: 10.1002/mmnz.4830410207

Karg, W. 1993. Acari (Acarina), Milben. Parasitiformes (Anactinochaeta). Cohors Gamasina Leach, Raubmilben. Die Tierwelt Deutschlands, 59: 1-523.

Kazemi, S. 2019. Mites of the genera Leioseius Berlese and Protogamasellus Karg (Mesostigmata, Ascidae) in mangrove forests in southern Iran, with a key to the genera and species of Ascidae recorded from Iran. Systematic and Applied Acarology, 24(7): 1319-1336. DOI: 10.11158/saa.24.7.14

Lindquist, E.E. 1975. Digamasellus Berlese, 1905, and Dendrolaelaps Halbert, 1915, with descriptions of new taxa of Digamasellidae (Acarina: Mesostigmata). Canadian Entomologist, 107: 1-43.

Lindquist, E.E. 1994. Some observations on the chaetotaxy of the caudal body region of gamasine mites (Acari: Mesostigmata), with a modified notation for some ventrolateral body setae. Acarologia, 35: 323-326.

Lindquist, E.E. and Evans, G.O. 1965. Taxonomic concepts in the Ascidae, with a modified setal nomenclature for the idiosoma of the Gamasina (Acarina: Mesostigmata). Memoirs of the Entomological Society of Canada, 47: 1-64.

Lindquist, E.E, Krantz, G.W. and Walter, D.E. 2009. Order Mesostigmata. In: G.W. Krantz and D.E. Walter (Eds.). A Manual of Acarology. $3^{\text {rd }}$ edition. Texas Tech University Press, Lubbock, pp. 124-232.

Lindquist, E.E. and Moraza, M.L. 2018. Review of the genus Leioseius Berlese, 1916 in North America, with description of two new species (Acari: Mesostigmata: Ascidae). Systematic and Applied Acarology, 23(10): 1986-2021. DOI: 10.11158/saa.23.10.10

Ma, L-M. 2002. [A new species of the genus Leioseius (Acari: Gamasina: Aceosejidae)]. Entomotaxonomia, 24: 154-156. [In Chinese]

Marchenko, I.I. 2012. Pochvennye gamazovye kleshchi (Acari, Mesostigmata) severa Sibiri [Soildwelling gamasid mites (Acari, Mesostigmata) of Northern Siberia]. Evraziatskii Entomologicheskii Zhurnal, 11 (6): 517-528. [In Russian]

Marchenko, I.I. 2017. Pochvennye gamazovye kleshchi (Acari, Mesostigmata) Sokhodinskogo zapovednika (Zabaykalskiy kray, Rossiya) [Soil gamasid mites (Acari, Mesostigmata) of Sokhondinskii Nature Reserve, Trans-Baikal Territory, Russia]. Evraziatskii Entomologicheskii Zhurnal, 16(2): 151-157. [In Russian]

Moraes, G.J., Britto, E.P.J., Mineiro, J.L. de C. and Halliday, B. 2016. Catalogue of the mite families Ascidae Voigts and Oudemans, Blattisociidae Garman and Melicharidae Hirschmann (Acaria: Mesostigmata). Zootaxa, 4112(1): 1-299. DOI: 10.11646/ zootaxa.4112.1.1

Nikolsky, V.V. 1981. Novye vidy gamazovych kleshchei iz yuzhnogo Primorya [New species of gamasid mites from southern Primorye]. In: A.I. Cherepanov (Ed.). Nasekomye i Kleshchi Sibiri. Novye i Maloizvestnye Vidy Fauny Sibiri. Akademiya Nauk SSSR. Sibirskoe Otdelenie. Biologicheskiy Institut, 15, pp. 14-22. [In Russian] 
Santos, J.C. and Moraes, G. J. 2016. A new species of Leioseius (Acari: Ascidae) from Brazil, redescription of Leioseius basis and a key for separation of the world species of the genus. Zootaxa, 4158: 52-64. DOI: 10.11646/zootaxa.4158.1.2

Shcherbak, G.I. 1980. Kleshchi semeystva Rhodacaridae Palearktiki [The Palearctic Mites of the family Rhodacaridae]. Naukova Dumka, Kyiv, 216 pp. [In Russian with English abstract]
Soper, R.S. and Olson, R.E. 1963. Survey of Biota Associated with Monochamus (Coleoptera: Cerambycidae) in Maine. Canadian Entomologist, 95: 83-95. DOI: 10.4039/Ent9583-1

Walter, D.E. and Krantz, G. W. 2009. Collecting, rearing and preparing specimens. In: G. W. Krantz and D.E. Walter (Eds.). A Manual of Acarology. $3^{\text {rd }}$ edition. Texas Tech University Press, Lubbock, Texas, pp. 83-95. 